\title{
A CLINICAL APPROACH OF RENAL INVOLVEMENT IN GRANULOMATOSIS WITH POLYANGIITIS
}

\author{
Marilena Stoian ${ }^{1 \cdot 2}$, Lucia Indrei ${ }^{1}$, Victor Stoica ${ }^{1}$ \\ "Carol Davila" University of Medicine and Pharmacy, Bucharest, Internal Medicine \\ 2"Internal Medicine Department," Dr. Ion Cantacuzino" Clinical Hospital, Bucharest \\ Correspondence to: Marilena Stoian, MD,PhD., 65, Matei Basarab Street, L109, sc 2, ap 27. \\ District 2, P.O. 030675, Bucharest, Romania \\ Fax:0214139917,E-mail : marilenastoian@yahoo.com
}

\begin{abstract}
Granulomatosis with polyangiitis (GPA, Wegener's granulomatosis) is one of the antineutrophil cytoplasmic antibody (ANCA) - associated small vessel vasculitis, involving various organs such as nasal septum, sinuses, upper respiratory tract, lungs, and kidneys. GPA is pathologically characterized by necrotizing granulomatous inflammation. ANCA-associated small vessel vasculitis represent a major challenge in hospital admissions; therefore, early and accurate diagnosis with aggressive treatment is essential to improve the disease outcome.

Renal involvement of granulomatosis with polyangiitis is characterized morphologically by extensive crescent formation (extracapillary proliferation in Bowman's space), and clinically by crescentic or rapidly progressive glomerulonephritis that causes hematuria, erythrocyte casts, and proteinuria with progressive loss of renal function. The diagnosis of granulomatosis with polyangiitis is established most securely by biopsy specimens showing the triad of vasculitis, granulomata, and large areas of necrosis (known as geographic necrosis) admitted with acute and chronic inflammatory cells. Usually, renal involvement is severe and is the leading cause of mortality. The combination of high-dose corticosteroids and cyclophosphamide is the mainstay of treatment for vasculitis and disease resistance to this combination is rare.
\end{abstract}

Keywords: granulomatosis with polyangiitis, vasculitis, crescentic glomerulonephritis, ANCA-small vessel vasculitis, anti-GBM glomerulonephritis.

\section{Rezumat}

Granulomatoza cu poliangeită (granulomatoza Wegener) este una dintre vasculitele vaselor mici asociată cu anticorpi anti-citoplasma neutrofilelor (ANCA), care implică diferite organe precum septul nazal, sinusurile, tractul respirator superior, plămânii și rinichii. Granulomatoza cu poliangeită este caracterizată histopatologic prin inflamație granulomatoasă necrotizantă. Vasculita vaselor mici asociată cu prezența ANCA reprezintă o provocare majoră, prin urmare, 


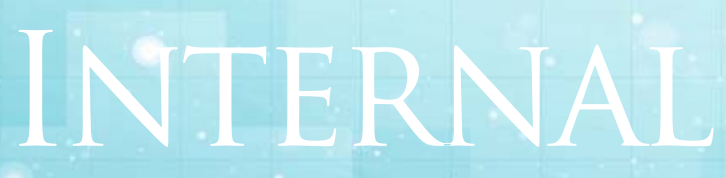

\section{General Reviews}

un diagnostic precoce și precis cu un tratament agresiv sunt esențiale pentru a îmbunătăți prognosticul bolii.

Implicarea renală în granulomatoza cu poliangeită se caracterizează histopatologic prin formarea extensivă a semilunelor (proliferare extracapilară în spațiul lui Bowman) și clinic prin glomerulonefrită crescentică sau rapid progresivă, care determină hematurie, cilindri eritrocitari și proteinurie, cu pierdere progresivă a funcției renale. Diagnosticul granulomatozei cu poliangeită este stabilit cel mai sigur prin analiza specimenelor biopsice, care arată triada vasculitei, granuloame și zone mari de necroză (cunoscută sub denumirea de necroză geografică), cu celule inflamatorii acute și cronice. De obicei, implicarea renală este severă și este principala cauză a mortalității. Tratamentul pentru vasculită se bazează pe combinația corticosteroizilor în doze crescute cu ciclofosfamida, rezistența la această combinație fiind rară.

Cuvinte cheie: granulomatoză cu poliangeită, vasculită, glomerulonefrită crescentică, vasculita vaselor mici asociată ANCA, glomerulonefrită anti-GBM.

Granulomatosis with polyangiitis or Wegener's granulomatosis or Wegener's arteritis or Wegener's disease is a disease involving granulomatous inflammation, necrosis and vasculitis that most frequently targets the upper respiratory tract, lower respiratory tract, and kidneys. It is seropositive for ANCAs, included in ANCA small vessel vasculitis. Renal involvement of granulomatosis with polyangitis is characterized morphologically by extensive crescent formation (extracapillary proliferation in Bowman's space), and clinically by crescentic or rapidly progressive glomerulonephritis that causes hematuria, erythrocyte casts, and proteinuria with progressive loss of renal function ' $\underline{1}$ '.

\section{Crescentic glomerulonephritis}

Crescentic glomerulonephritis is not a specific disease but rather is a morphologic expression of severe glomerular injury that can be caused by many different etiologies and pathogenic mechanisms $\underline{1}^{(2)}$. Crescent formation appears to represent a nonspecific response to severe injury to the glomerular capillary wall ${ }^{(3)}$. Rents (focal gaps or discontinuities of the capillary wall) are induced in the glomerular capillary wall, resulting in the movement of plasma products, including fibrinogen, into Bowman's space with subsequent fibrin formation, the 
influx of macrophages and $T$ cells, and the release of proinflammatory cytokines, such as interleukin-1 and tumor necrosis factor-alpha ${ }^{(4)}$ and procoagulant and fibrinolytic inhibitory factors. The stage of active inflammation is often followed by the development of fibrocellular and fibrous crescents' $\underline{4}$ '. Collagen deposition is due to fibroblast proliferation that is driven by fibroblast growth factors. Transforming growth factor-beta is also thought to play an important role. This transition is important clinically because fibrous crescents represent a stage of the disease that is not likely to respond to immunosuppressive therapy. Because this structural phenotype indicates severe glomerular injury, it is not surprising that it usually correlates with clinical manifestations of severe active glomerulonephritis and rapid loss of renal function ( rapidly progressive glomerulonephritis (RPGN).Rapid and accurate diagnosis of crescentic glomerulonephritis is essential for patient prognosis; so it is important the strong correlation between outcome and serum creatinine at the time of initiation of treatment.

The term rapidly progressive glomerulonephritis (RPGN) in the context of crescentic glomerulonephritis (CGN) is usually due to one of three broad mechanisms of glomerular injury : circulating anti-GMB antibodies with linear glomerular IF staining ; glomerular immune complex localization with granular IF staining ; circulating ANCA with paucity of glomerular IF immunoglobulin staining (figure 1)' $\underline{1}^{\prime}$.

\section{Anti-GBM Disease}

Anti-GBM glomerulonephritis is caused by autoantibodies directed against the alpha 3 chain of type IV collagen $(\underline{5,6}$. Anti-GBM glomerulonephritis has the most severe glomerular injury at the time of biopsy, which correlates with, and is the basis for, its aggressive clinical manifestations. Approximately half of patients with anti-GBM glomerulonephritis have pulmonary hemorrhage, and thus manifest pulmonaryrenal vasculitis syndrome. ANCA glomerulonephritis with ANCA -pulmonary capillaritis more often is the cause for pulmonary- renal vasculitis syndrome than

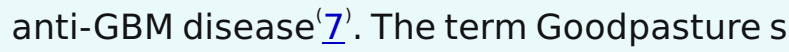
syndrome is reserved for patients with pulmonary-renal vasculitis syndrome caused by anti-GBM antibodies. Approximately a third to a quarter of patients with anti- GBM disease also are ANCA -positive $\underline{\boldsymbol{8}}^{9)}$. This is an important determination to make, because anti-GBM patients with ANCA are at risk for developing small vessel vasculitis in other organs than kidneys and lung, and may have recurrences of ANCA -disease after the antiGBM disease has resolved.

\section{Immune complex crescentic glomerulo- nephritis}

Immune complex crescentic glomerulonephritis has less often crescent formation than anti-GBM glomerulonephritis or ANCA glomerulonephritis and this is why it's a less aggressive category of crescentic glomerulonephritis ${ }^{(2,10)}$. Within a given category of immune complex glomerulonephritis, the prognosis correlates directly with the percentage of crescents. However, the prognostic significance of a given percentage crescents is not the same in different categories. For example, a patient with diffuse proliferative lupus glomerulonephritis who has $25 \%$ crescents has a much worse prognosis than a patient with post-streptococcal acute diffuse proliferative glomerulonephritis and $25 \%$ crescents. 


\section{INTERNAL}

\section{General Reviews}

\section{ANCA-Small vessel vasculitis and glomerulonephritis}

When glomeruli in patients with crescentic glomerulonephritis are evaluated for the presence of immunoglobulins, most patients do not have evidence for either immune complex or anti -GBM localization ${ }^{(2,11)}$. These patients have ANCA in their circulation. These autoantibodies react with proteins in the primary granules of neutrophils and the lysosomes of monocytes, and may be pathogenic $^{(12)}$.

The antigen specificity of ANCA in patients with glomerulonephritis is usually for proteinase 3 (PR 3 - ANCA) or myeloperoxidase (MPO-ANCA) ${ }^{(12,13)}$. PR3ANCA usually cause cytoplasmic staining of neutrophils in indirect immunofluorescence assays (C-ANCA), whereas MPO-ANCA usually cause perinuclear staining ( $P$ ANCA).C-ANCA have a particularly strong connection to granulomatosis with Polyangiitis (up to $80 \%$ of patients - and possibly more of those with active disease have these antibodies). When C-ANCA are present in the blood of a patient whose symptoms or signs suggest granulomatosis with polyangiitis, the likelihood of the diagnosis increases considerably. In most cases, however, it is still VERY IMPORTANT to biopsy an involved organ to verify the diagnosis.
ANCA-glomerulonephritis may occur as a renal -limited disease; three-quarters of patients with ANCA -glomerulonephritis have evidence for small vessel vasculitis. ANCA small vessel vasculitis includes microscopic polyangitis granulomatosis with polyangiitis, and Churg-Strauss syndrome. These diseases are characterized by systemic necrotizing small vessel vasculitis that can affect arteries, arterioles, capillaries, venules, and veins ${ }^{(14)}$. Granulomatosis with polyangiitis is a disease involving granulomatous inflammation, necrosis and vasculitis that most frequently targets the upper respiratory tract, lower respiratory tract, and kidneys. Although granulomatosis with polyangiitis can begin at any age, the average age of onset is about 40 years. Other organs frequently affected by granulomatosis with polyangitis granulomatosis include the eye (proptosis and double-vision from retro-orbital pseudotumor, scleritis), skin (ulcers, purpura). or peripheral nerve (mononeuritis multiplex).

Granulomatosis with polyangiitis may be limited to one site for many months or years before disseminating. Systemic symptoms (fever, fatigue, weight loss) are also common. Anemia, mild leukocytosis, and elevated erythrocyte sedimentation rate (ESR) are nonspecific laboratory findings. Chest radiographs often show infiltrates, 


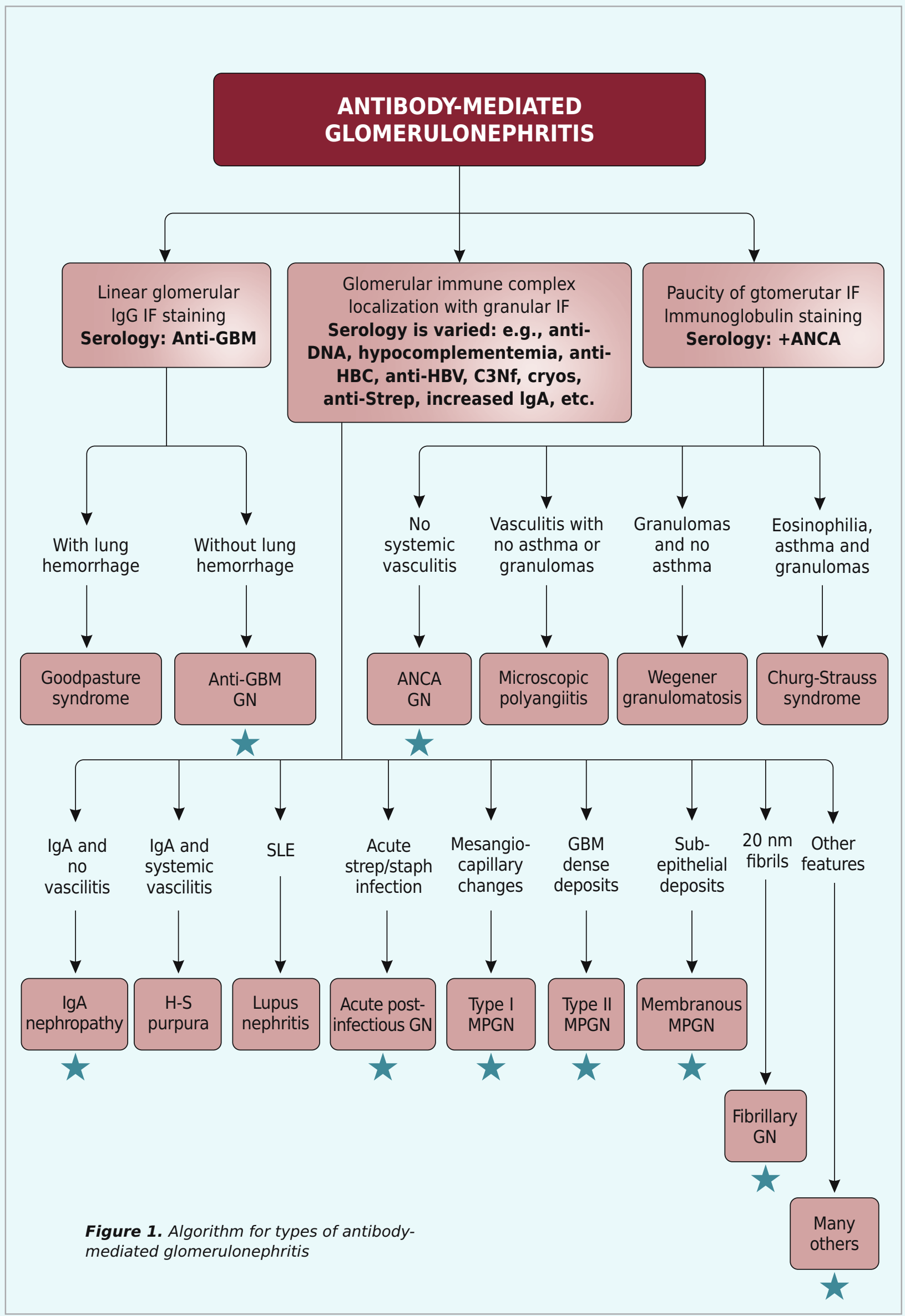




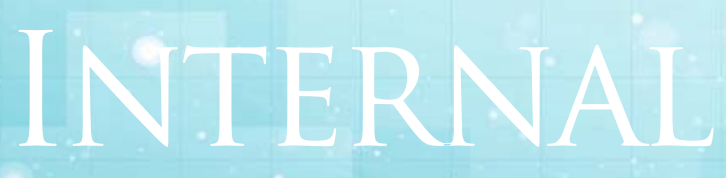

General Reviews

nodules, masses, or cavities; only hilar adenopathy is incompatible with the diagnosis of granulomatosis with polyangiitis. CT of the chest is more sensitive than chest radiography and can be abnormal when the chest radiograph is negative. Glomerulonephritis causes hematuria, erythrocyte casts, and proteinuria.

A novel group of autoantibodies, ANCAs, helps support the diagnosis of granulomatosis with polyangiitis and related forms of vasculitis and gives insight into the pathogenesis of these diseases. ANCAs are directed against enzymes contained in primary granules of neutrophils and monocytes. Two main types of ANCAs are recognized.

The C-ANCAs are directed against serine proteinase 3 and are relatively sensitive and highly specific for granulomatosis with polyangiitis. The P-ANCAs are directed against myeloperoxidase and other antigens and are not specific for any single form of vasculitis, but have been seen in some patients with granulomatosis with polyangiitis, polyarteritis nodosa, ChurgStrauss vasculitis, and some forms of pauciimmune glomerulonephritis (referred to as microscopic polyarteritis nodosa). Some patients with pulmonary-renal syndromes that may not fit the criteria for granulomatosis with polyangiitis are also seropositive for ANCAs. Some patients with inflammatory bowel disease, rheumatoid arthritis, or SLE may have atypical P-ANCA test results, based on the autoantibodies directed against other neutrophil constituents such as lactoferrin.

ANCAs may be not only markers for granulomatosis with polyangiitis and related disorders, but they may also be actors in pathogenesis. Studies show that when neutrophils are exposed to cytokines such as tumor necrosis factor, small amounts of serine proteinase and myeloperoxidase, the targets for ANCAs, are expressed on the surface of neutrophils. Adding ANCAs to these cytokine-primed neutrophils causes them to generate oxygen radicals and release enzymes capable of damaging blood vessels.

The diagnosis of granulomatosis with polyangiitis is established most securely by biopsy specimens showing the triad of vasculitis, granulomata, and large areas of necrosis (known as geographic necrosis) admitted with acute and chronic inflammatory cells.

Only large sections of lung tissue obtained via thoracoscopic or open lung biopsy are likely to show all of the histologic features. However, more easily obtained biopsy specimens of the nose, or sinuses may show several of the changes that are highly suggestive of granulomatosis with polyangitis. Such a biopsy specimen 
combined with a compatible clinical picture and seropositivity for C-ANCAs should suffice to secure the diagnosis. Seropositivity for CANCAs alone is not specific enough to establish the diagnosis of granulomatosis with polyangiitis.

Untreated granulomatosis with polyangiitis is fatal. Prednisone may slow progression of the disease but by itself is insufficient to arrest the disease.

Respiratory tract disease usually progresses slowly, but renal disease can progress rapidly and therefore warrants urgent evaluation and treatment. With the traditional treatment of prednisone (initiated at $1 \mathrm{mg} / \mathrm{kg}$ daily for 1 to 2 months. then tapered) and cyclophosphamide $(2 \mathrm{mg} / \mathrm{kg}$ daily for at least 12 months), more than $90 \%$ of patients improve and $75 \%$ remit. However, $50 \%$ of the patients who later remit also relapse, and oral daily cyclophosphamide causes serious toxicity. Short-term toxicity includes cytopenia, infection, and hemorrhagic cystitis.

Long-term use of cyclophosphamide in patients with granulomatosis with polyangiitis more than doubles the risk of cancer overall, increases the risk of bladder cancer 33-fold and the risk of lymphoma 11fold. Monthly intravenous cyclophosphamide appears less toxic but also less effective. Weekly, methotrexate appears to be an effective alternative for granulomatosis with polyangiitis that is not immediately lifethreatening, and it also appears to be beneficial in maintaining remission. The role of trimethoprim-sulfamethoxazole in treating active disease is controversial, with some finding it effective for granulomatosis with polyangiitis limited to the respiratory tract, and others not. In patients who have achieved remission, trimethoprimsulfamethoxazole reduces the relapse rate.

\section{Treatment: point of view}

\section{Remission induction}

- If mild disease $>$ glucocorticoids + methotrexate (MTX)

- !!Patients who do not benefit from MTX may be switched to either cyclophosphamide or rituximab.

- If moderate to severe disease > glucocorticoids + either cyclophosphamide or rituximab PCP prophylaxis in patients receiving cyclophosphamide and corticosteroids: trimethoprim/sulfamethoxazole (TMP/SMX)

- Glucocorticoids should be tapered gradually as soon as the patient begins responding to the immunosuppressant agent.

Remission maintenance: immunosuppressive drugs (e.g., azathioprine, rituximab or methotrexate)

\section{References}

1. Couser WG. Rapidly progressive glomerulonephritis: classification, pathogenetic mechanisms, and therapy. Am J Kidney Dis 1988; 11:449

2. Jennette JC, Olson JL, Schwartz MM, Silva FG, eds. Crescentic glomerulonephritis. Heptinstall s Pathology of the Kidney, 5th edn 1988;625-656.

3. Moutzouris L, Appel GB, et al. Renal biopsy in the very elderly. Clin J Am Soc 2009; 4:1073.

4. Nair R, Bell JM, Walker PD. Renal biopsy in patients aged 80 years and older. AmJ Kidney Dis 2004; 44:618.

5. Kalluri $R$, Wilson $C B$, Weber $M$ et al. Identification of the alpha 3 chain of type IV collagen as the common autoantigen in antibasement membrane disease and Goodpasture syndrome. J Am Soc Nephrol 1995; 6: 1178-1185.

6. Hellmark T, Johansson C, Wielander J. Characterization of anti-GMB antibodies involved in Goodpasture s syndrome. Kidney Int 1994; 46:823-839.

7. NilesJL, Bottinger EP, Saurina GRet al. The syndrome of lung hemorrhage and nephritis is usually an ANCAassociated condition. Arch Intern Med 1996; 156:440

8. Jennette JC. Rapidly progressive crescentic glomerulonephritis. Kidney Int 2003; 63:1164.

9. Hellmark $T$, Niles JL,Collins AB, Brunmark $C$. 


\section{INTERNAL}

General Reviews

Comparison of anti-GBM antibodies in area with or without ANCA . J Am Soc Nephrol 1997; 8: 376-385

10. Baldwin DS. Kidney Int 1987; 31:790.

11. Seo P, Stone JH. The antineutrophil cytoplasmic antibody-associated. Am J Med 2004; 117:39.

12. Jennette JC, Falk RJ. Pathogenesis of the vascular and glomerular damage in ANCA-positive vasculitis.Nephrol Dial Transplant 1998;13: S16-S20.

13. Jennette JC, Falk RJ. Small vessel vasculitis. N EnglJ Med 1997; 337:1512-1523.

14. Jennette JC, Thomas DB, Falk RJ. Microscopic polyangiitis. Semin Diagnostic Pathol 2001; 18:3-13.

15. Kasper DL, Fauci AS, Hauser SL, Longo DL, Lameson JL, Loscalzo J. Harrison's Principles of Internal Medicine. New York, NY: McGraw-Hill Education; 2015: pp. 21842185.

16. Tracy CL. Granulomatosis with Polyangiitis (Wegener Granulomatosis). In: Granulomatosis with Polyangiitis (Wegener Granulomatosis). New York, NY:
WebMD. http://emedicine.medscape. com/article/ 332622-overview. Updated November 21, 2016. Accessed April 13, 2017.

17. Falk RJ. Maintenance immunosuppressive therapy in granulomatosis with polyangiitis and microscopic polyangiitis. In: Post TW, ed. UpToDate. Waltham, MA: UpToDate. http://www.uptodate.com/contents/ maintenance-immunosuppressive-therapy-ingranulomatosis-with-polyangiitis-and-microscopicpolyangiitis. Last updated January 13, 2016. Accessed April 13, 2017.

18. Merkel PA, Kaplan AA, Falk RJ. Initial immunosuppressive therapy in granulomatosis with polyangiitis and microscopic polyangiitis. In: Post TW, ed. UpToDate. Waltham, MA: UpToDate. http://www.uptodate.com/contents/initialimmunosuppressive-therapy-in-granulomatosis-withpolyangiitis-and-microscopic-polyangiitis. Last updated January 4, 2017. Accessed April 13, 2017 